\title{
The Two Institutional Logics: Exit-Oriented Versus Commitment-Oriented Institutional Designs
}

\author{
DAVID ELLERMAN
}

Economics Department, University of California at Riverside, Riverside, USA

\begin{abstract}
Throughout human affairs there are two dual logics. Albert Hirschman investigated the two logics as the parallel-oriented logic of exit and the series-oriented logic of commitment, loyalty, and voice. Economics focuses almost exclusively on the logic of exit and questions of institutional design are seen through that lens. One goal here is to flesh out the alternative commitment-oriented logic of institutional design. The large Japanese-style firm is a major example of the commitment-oriented institutional design. Another point is that each logic has an internal consistency so some 'mix and match' hybrids can be more lethal than vigorous. In the East Asian crisis, highly leveraged firms from a commitment-oriented system of relational finance had 'taken advantage' of the new funds available from globalized financiers operating under the exit-oriented logic of arms-length finance - and the hybrid proved to be unviable. Overall, my goal is to illustrate the two institutional logics that offer two different and often incompatible ways to approach questions of flexibility, performance, and efficiency.
\end{abstract}

KEY WORDS: Exit, voice, commitment, lethal hybrids JEL Classification: A12, D21

Correspondence Address: David Ellerman, Economics Department, University of California at Riverside, Riverside, CA 92521, USA. Email: david@ellerman.org 


\section{Introduction: The Two Logics}

There are two logics, dual to one another, that run throughout mathematics and the sciences as well as throughout questions of institutional design. The underlying duality is series-parallel duality that is best-known from electrical circuit theory. ${ }^{1}$ The underlying model is the basic choice between multiple components connected in parallel or connected in series as in the twoterminal circuits in Figure 1.

In a tree search model, there is the branching of a stem into parallel boxes and there is the series connection of boxes to make a long branch. In searching over a tree, there are two logics. If the answer is not found in box A (see Figure 2), does one backtrack and exit the A branch and try a parallel branch (B or $\mathrm{C}$ ), or does one stay committed to the A branch and try further boxes along it (A1 or A2)? If one chooses A1 and it is unsatisfactory ('doesn't have the answer'), then one has the choice to backtrack and exit the A1 branch and try A2 (or exit again to try $\mathrm{B}$ or $\mathrm{C}$ ), or to stay committed to the A1 branch and try the further refinements A11 or A12.

The choice is between the parallel-oriented breadth-first strategy and the series-oriented depth-first strategy. 'The ideas of breadth and depth are in competition throughout the whole history of combinatorial optimization' (Strang, 1986: 609).

The main work on this topic in human affairs is Albert Hirschman's (1970) development of the contrast between the parallel-oriented logic of exit (exit the branch to try other branches) and the series-oriented logic of voice, loyalty, and commitment (stay loyal and committed to the given branch by searching further along it). ${ }^{2}$

As a variation on the tree model, we could think of options with characteristics. Suppose one has an option with unsatisfactory characteristics. Does one treat the characteristics as fixed and then seek improvement by exiting the option to find a better one? Or does one stick with the given option and try to change the characteristics for the better ${ }^{3}$ Hirschman referred to the change-the-characteristics strategy as voice: 'Voice is here defined as any attempt at all to change, rather than to escape from, an objectionable state of affairs...' (Hirschman, 1970: 30). These two logics of exit or voice (commitment) are quite common in human affairs. Does the 'unhappy camper' fold his tent and look for a better campsite or does he work to make the

\footnotetext{
${ }^{1}$ The duality that is more familiar in economics is convex duality (Rockafellar, 1970). The dualities are related; convex duality is the integral or anti-derivative of series-parallel duality (see 'Parallel addition, series-parallel duality, and financial mathematics,' chapter 12 in Ellerman, 1995).

${ }^{2}$ Jane Jacobs (1992) develops a variation of the theme with the contrast between the exitoriented commercial syndrome and the commitment-oriented guardian syndrome.

${ }^{3}$ In the correspondence between the tree search model and the options-characteristics model, the breadth-first strategy corresponds to treating characteristics as fixed so as to favour exit (from A to B or C), and the depth-first model corresponds to sticking with an option but trying to change its characteristics (from A to A1 or A2).
} 

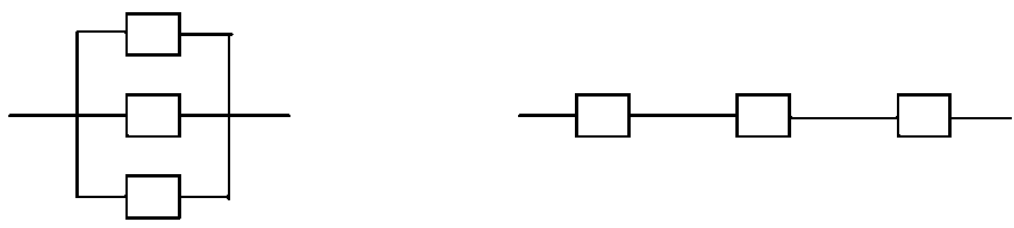

Figure 1. Parallel and series connections of components

given campsite better? Every potential migrant faces the question: exit to find a better home or commit to making home better?

Managers constantly face similar decisions. When a team of workers is not performing satisfactorily, the manager has two choices. One choice is to take the capabilities of the team members as fixed so that people need to be shuffled in and out of the team until the right team characteristics are obtained. Or a manager might proceed with more commitment to the team members and then try to work with them to better develop their capabilities until the team performed satisfactorily.

The two logics are quite ubiquitous. I will call the parallel-oriented approach, the logic of exit. Decline and dissatisfaction leads to exit and replacement. I will call the series-oriented approach using voice, the logic of commitment. ${ }^{4}$ Decline and dissatisfaction leads to renewed commitment and the attempt to transform the characteristics (e.g. through the exercise of voice).

\section{Five Points on the Two Logics}

My first point is simply the ubiquity of the two logics - as I hope will become clear in the course of the argument. I will focus on cases where the two system logics are incompatible rather than cases where they need to be blended to find the best system.

The second point is that sometimes there seems to be an awareness of only one logic, e.g. the belief that improvement can only come through exit and replacement. For a trivial example, young people might think that the only response to a dull razor blade is to throw it away and replace it with a new sharp blade. But in 'the old days' there were straight razors; when the blade got dull, one would sharpen it. This is an example of the two logics as the replace versus repair strategies: buy cheap replaceable items and replace as necessary, or buy more expensive quality items and repair as necessary.

The third point is that often the desired performance can be obtained by using a system based on either the logic of exit or the logic of commitment. Both ways are possible; the best system will depend on the particular circumstances.

\footnotetext{
${ }^{4}$ The expressions 'logic of exit' and 'logic of commitment' are used by Kagono \& Kobayashi (1994) who develop the two logics of organizational design by contrasting the American-style firm and the Japanese-style firm (see the section below on 'The Modern Japanese Company').
} 


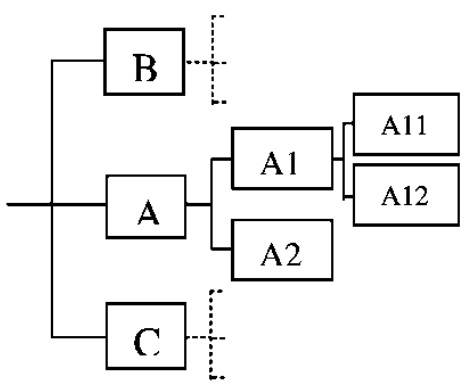

Figure 2. Breadth-first search versus depth-first search

The fourth point is that there are often interdependencies in a system based on one of the logics so that hybrids tend to be lethal rather than vigorous. If one tries to 'mix and match' exit-based components with commitment-based components, then the system will most likely malfunction. ${ }^{5}$

For instance, in an exit-based system of conflictual labour relations, large inventories help to mitigate the hold-up problem of workers going on strike. A just-in-time inventory system fits together with cooperative labour relations. But if a company with conflictual labour relations decides to try a just-in-time system to save on inventory costs, then any labour conflicts (e.g. truckers) will lead to costly hold-ups for the company.

Or in an exit-oriented system of arms-length finance, companies need low leverage and a large equity buffer since, when the company hits some turbulence, their financiers may not be willing to extend or rollover their loans. But in a commitment-oriented system of relational finance, firms can have more leverage since their financiers are expected to stay committed in times of trouble. ${ }^{6}$

One of the (partial) explanations for the East Asian crisis in the late 1990s was that the globalization of finance tempted highly leveraged firms in countries that historically had relational finance (e.g. Korea) to 'take advantage' of the cheap and easy finance available from international (arms-length) financiers. But then small shocks to the new 'hybrid' system were soon amplified to a crisis when arms-length financiers did not rollover loans and firms had too much leverage to ride out the shocks. In such a system that got stuck halfway between the two system logics, there are two basic policy options. One option is to make a wholesale conversion to an exit-based system of arms-length finance. The other option is to curtail the impact of the exitbased features to maintain functionality in a modernized commitmentbased system, e.g. using capital controls to install 'speed bumps' on the 'hot money highway' of globalized arms-length finance.

\footnotetext{
${ }^{5}$ See Jacobs's (1992) analysis of corruption resulting from a 'monstrous hybrid' between the commercial and guardian syndromes.

${ }^{6}$ See Goldberg (1980) for the contrast between relational and arms-length contracts.
} 
The fifth point is that while one system logic may be appropriate in one case and the other logic in another case, there is however a 'worst of both worlds' hybrid which combines the fixed characteristics of the one logic with the fixity of the option in the other logic. If both the option and the characteristics are fixed, then one has an unviable 'lethal hybrid' that cannot change in the face of adversity and decline. Unfortunately, some attempts to create hybrids with the virtues of both logics may end up with the worst case that only combines their vices. ${ }^{7}$ And some attempts to jump over the chasm by converting a system based on one logic into a system with the other logic may stall halfway across and fall into the chasm to get the 'worst of both worlds.'

I am focusing on cases where the two logics tend to be antagonistic or mutually exclusive (i.e. hybrids are more lethal than vigorous) so that the system needs to be based on one logic or the other. If the two logics are on the two axes, then we are interested in cases where the best solution is a corner solution.

There is a whole range of cases where the two logics are complementary rather than antagonistic. The logics appear as two 'moments' that need to be optimally combined to have the best solution. Then the best case is not a corner solution but some convex combination of the two moments. For instance in complex adaptive systems, the parallel-oriented moment is called exploration (or variation) and the series-oriented moment is exploitation (or selection). ${ }^{8}$ If the goal of the model is to reach a higher altitude on a rugged and cloudy 'adaptive landscape' then exploitation means staying committed to the given hill and climbing higher on it, while exploration means jumping, traversing, or otherwise exiting to another hill that may be higher. In such a system, a corner solution would not work. A system with all exploration would jump in an agitated manner from hill to hill without settling down to climbing higher on any hill. A system with all exploitation would only climb the hill it is on, and so it would tend to get stuck on a low hill. ${ }^{9}$

\section{The Two Ways to Handle Risks}

\section{Two Ways to put Eggs in Baskets}

One of my theses is that often there seems to an awareness of only one system logic to the exclusion of the other. This is probably nowhere more true than in

\footnotetext{
${ }^{7}$ For instance, many Panglossian treatments of migration and development see people using the 'exit to find a better home' logic but then either returning from a 'temporary' migration with needed skills or at least sending back remittances to fuel local development so that the virtue of 'committing to make home better' will also be realized. But, as the saying goes, 'there is nothing more permanent than "temporary' migration"' and the remittances are spent largely for consumption purposes (see Jacobs, 1984: 122 on remittances; and overall see Ellerman, 2003). In this case, the desire to take the exit logic but still get the virtues of the other logic has largely proved to be a vain hope.

${ }^{8}$ See, for example, Pagels (1988) or Axelrod \& Cohen (1999).

${ }^{9}$ Economists often assume a simplified 'one hill' model where hill-climbing mechanisms (local optimization) will suffice.
} 


\section{2}

neoclassical economics, which is based on the exit-oriented logic of the market. But the one-sidedness also extends to basic questions of handling risks. One often finds the almost knee-jerk response to any risk problem; the solution is the parallel-oriented strategy of diversification. Don't put all your eggs in one basket. Use one's resources to place many small bets rather than one or a few large bets. In terms of a tree search, this is the strategy of making an extensive parallel search of the first boxes on many different branches rather than an intensive search over the series of boxes along one branch.

The usual diversification recommendation to 'spread your eggs between many baskets' makes the implicit assumption that the baskets have fixed characteristics (e.g. a fixed probability that the eggs in a basket will be broken by the basket tipping over or being dropped). But if the characteristics of some baskets can be significantly changed by a commitment of attention and control to one or a few baskets, then the dual risk reduction strategy emerges. Put all your eggs in one or a few baskets, watch them very carefully, and make sure the baskets are not tipped over or dropped. ${ }^{10}$

The logic of commitment enters through the door of flexible characteristics - in this case the risk characteristics. The probabilities of a person having an accident might not be fixed independently of the person's activities but might depend on the precautions taken by the person. When the logic of exit (diversification) works too well, e.g. complete insurance against the consequences of accidents, then the insured will neglect taking precautions and hazards will increase, i.e. moral hazard. To combat moral hazard, one has to move back a little ways toward the logic of commitment by exposing the insured to some of the costs of accidents, e.g. deductibles and co-pay in medical insurance.

This foreshadows a basic theme. When the choice environment is parsed into a set of options each having certain characteristics, the choice of a commitment-oriented strategy or an exit-oriented strategy will in part depend, respectively, on the extent to which the characteristics are flexible or are fixed.

\section{Two Biological Reproductive Strategies}

The choice of risk reduction strategy hinges on the question of whether or not a commitment of resources to one or a few options can significantly change the risk characteristics of those options. In biology, all organisms face the reproductive risk that their genes may not survive into the next generation. Since organisms only have limited reproductive resources to address this risk problem, they tend to 'choose' one or the other of the 'corner solutions' to solving this risk reduction problem.

\footnotetext{
${ }^{10}$ Hence probability theory neglects the dual risk reduction strategy when it takes the probability distribution as being independent of the 'bets' made on each outcome.
} 
If organisms have little or no control over the risk characteristics faced by their offspring, then the organisms will tend to favour a diversification strategy called $r$ selection. They spread their reproductive resources over many offspring as with most insects and fish, ${ }^{11}$ and then the offspring face the odds with little or no parental assistance. The emphasis is on the quantity rather than quality of offspring. However, if the parents can significantly control the risk characteristics faced by their offspring and if the offspring can be produced with a 'quality' to improve their odds, then that species will tend to favour the commitment-oriented strategy called $K$ selection. They invest their reproductive resources in a few 'quality' offspring as with mammals and then they provide intensive parental care to the offspring.

\section{Two Ways to Increase Reliability}

Another example is from reliability theory in engineering. The risk is system failure when a component breaks down. The parallel-oriented approach to reducing that risk (increasing reliability) is redundancy. In the general parallel (exit-oriented) case, there may be two ways to explore parallel options, one at a time or, if possible, simultaneously. One form of exit-oriented behaviour is to try one option, then another, and so forth. Another form of exit-oriented behaviour is to try many options simultaneously as when eggs are spread between many baskets or when biological resources are spread over many offspring. These two forms of the parallel-oriented approach come out clearly in reliability theory.

The one-at-a-time approach to redundancy (parallelism) is called standby redundancy. The system uses one option or subsystem until it breaks down and then it switches to the standby system. An aeroplane might have a standby radio or navigational system; if the primary system breaks down, it can switch to the standby system. The simultaneous approach to parallelism is called active-parallel redundancy. For instance, an aeroplane with several engines is using active-parallel redundancy; if one engine breaks down, hopefully the others will suffice to land the plane safely. Otherwise they may have to switch to the standby way of getting to the ground safely, parachutes.

Scarce resources are used to build reliability into a system. In some cases, using redundancy to increase reliability may not be technologically possible. The dual way to increase reliability is to use resources to improve the reliability characteristics of the components of the one system. Thus, the trade-off between the two logics in using resources to reduce risks and increase reliability is 'Redundancy versus improved elements' (Von Alven, 1964: 240).

\footnotetext{
${ }^{11}$ Species such as the social insects (e.g. bees and ants) that can create a controlled microenvironment to protect their young (beehive or ant hill) will use the K-selection strategy.
} 
These examples illustrate the second point that there is another way to reduce risks than just distributing one's eggs between many baskets.

\section{The Two Ways to Get Flexibility, Performance and Efficiency \\ Flexible Options or Flexible Characteristics in Given Option?}

In the options and characteristics model, the two system logics differ by what is fixed and what is flexible. With the parallel- or exit-oriented logic, the characteristics of an option are taken as fixed so flexibility is obtained by exiting one option and taking another. If workers do not have the desired skills for a new technology, then relocate or fire those workers and hire others with the desired characteristics. With the series- or commitmentoriented logic, the option is taken as fixed so flexibility is obtained by changing the characteristics of the option. Workers with some commitment from the company for employment security would be more willing to learn new skills and retrain for new technologies since they would not be 'working themselves out of a job'. It is not a question of flexibility or not, but of achieving flexibility in one way in one system or in another way in another system.

Exit versus commitment are the two logics that run through the design of institutions. The market is an institution that operates largely on the basis of the logic of exit. Economics developed first as the theory of markets and market behaviour, so economics tends to see the world through an exitoriented lens.

The economist tends naturally to think that his mechanism (exit) is far more efficient and is in fact the only one to be taken seriously. (Hirschman, 1970: 16)

Organizations (including political units or polities) would seem to be the natural setting for commitment-based strategies. If there are some costs or barriers to exit in the face of dissatisfaction, then the exercise of voice may be the better way to change things. Hence one might expect to see organizations designed on the basis of the logic of commitment.

\section{Allocative Efficiency or X-efficiency?}

More broadly, take an option to be a particular use of a resource and take the characteristic of the resource to be its productivity or effectiveness in that use. Then the two system logics give two ways to get improved performance and efficiency. The exit-oriented strategy is to move resources to higherproductivity uses (e.g. through the market) and the commitment-oriented strategy is to get higher productivity out of resources in the given use (e.g. in an organization). The exit-oriented notion of efficiency is allocative efficiency associated with markets. Resources in a certain use have fixed productivity so it is a question of the allocation of resources to the highervalued uses. The commitment-oriented notion of efficiency is X-efficiency 
(Leibenstein, 1966, 1984) where the principal variable productivity of a resource in a given use (e.g. in an organization) is human effort. ${ }^{12}$

If a skill is quite standardized and available on the market, then in that case the exit-oriented logic can work in a firm. The threat of dismissal calls forth more effort. The low-trust system is self-reinforcing in its system logic. Low trust leads to highly explicit contracts with competitive arms-length relationships with no need to invest in building trust or loyalty, and thus the low-trust environment is reproduced.

However, the logic plays out differently when the jobs require more firmspecific skills and where the quality of effort is not only variable but largely hidden. If there was little mutual commitment between the staff and the management, then the staff would have little reason to put forth hidden effort and little incentive to invest time and effort in acquiring firm-specific skills. And management would have little incentive in upgrading staff skills that are not firm-specific since the staff might then solicit and accept an offer from another firm that would not need to repeat the training. In firms where firm-specific 'human capital' and quality effort are important, the human relations system will tend towards a commitment-based logic (see Blair, 1995). A labour union can be a positive contributor to such a human relations strategy (see Freeman \& Medoff, 1984). High trust relationships allow more incomplete relational contracts, which require investment in building trust and loyalty so that the high trust environment will be reproduced.

Since low-trust exit-oriented relationships and high-trust commitmentoriented relationships each tend to be self-reinforcing, there are two organizational equilibria. For instance, in Douglas McGregor's (1960) management theory, the two equilibria based on the two logics are 'Theory X' and 'Theory Y'.

There is also a motivational aspect to these two logics. The exit-oriented logic emphasized in economics goes along with extrinsic pecuniary motivation. But successful organizations sponsor another type of motivation where the individual 'identifies' with the product and the organization, and also where the management shows that it 'identifies' with the company staff (all of which might be seen as an 'implicit contract' between management and the workers). That is the motivational side of the internal commitment-oriented logic in the organization.

In the literature of economics, Herbert Simon has perhaps done the most to emphasize the inadequacy of exit-based reasoning and pecuniary motivation to account for organizational behaviour.

A department will be less likely to skimp on quality to cut costs if its members identify with the final product. In particular, identification

\footnotetext{
${ }^{12}$ Notice that the exercise of voice now appears as the exercise or calling forth of effort broadly interpreted. Although the terminology of X-efficiency came later, Hirschman has emphasized the importance of the alternative notion of efficiency in economic development: 'development depends not so much on finding optimal combinations for given resources and factors of production as on calling forth and enlisting for development purposes resources and abilities that are hidden, scattered, or badly utilized.' (Hirschman, 1958: 5).
} 
becomes an important means for removing or reducing those inefficiencies that are labeled by the terms 'moral hazard' and 'opportunism'. (Simon, 1991: 41) ${ }^{13}$

Organizations are so important in modern economies and neoclassical economics is so one-sided in its focus on the exit-oriented market logic that Simon considers the theory to be quite incomplete.

The economies of modern industrialized society can more appropriately be labeled organizational economies than market economies. Thus, even market-driven capitalist economies need a theory of organizations as much as they need a theory of markets. The attempts of the new institutional economics to explain organizational behavior solely in terms of agency, asymmetric information, transaction costs, opportunism, and other concepts drawn from neo-classical economics ignore key organizational mechanisms like authority, identification, and coordination, and hence are seriously incomplete. (Simon, 1991: 42)

\section{The Modern Widely-Held American Company}

If the exit logic fits markets and the commitment logic fits organizations, then what would an organization look like if it were based on the logic of exit? This brings us to the 'model' of the widely-held American corporation. To apply the exit logic, there is one complication. Who's in and who's out? Who are the members of the organization?

There are actually 'two companies': the company as a legal entity and the company as a working group of human beings. ${ }^{14}$ The legal entity, the legal or de jure firm, has the shareholders as the members. But the members of the actual or de facto firm are the managers and workers who actually carry out the company's business. In a small closely-held company, the de jure firm and the de facto firm are largely the same. But for the large modern publicly traded American company, there is very little overlap between the de jure firm (shareholders) and the de facto firm (employees including managers). Those who are actually inside the company (the staff) are, from the legal viewpoint, outside the firm and have only a market relationship (employment) to the firm. Those who are legally inside the company (the legal members of the company), are the far-flung shareholders who typically have no business relationship with the company aside from the share ownership and who typically have well diversified portfolios of shares (see Figure 3).

The commitment-oriented logic of organizational design would be appropriate for a company, but the problem is that there are the two companies. The commitment-oriented design is applied, at best, to the de jure

\footnotetext{
${ }^{13}$ Here again we see the logic of commitment being used to combat moral hazard.

${ }^{14}$ For instance, in the management literature this is closely related to W. Richard Scott's (1998) distinction between a corporation as a 'rational system' and as a 'natural system'.
} 


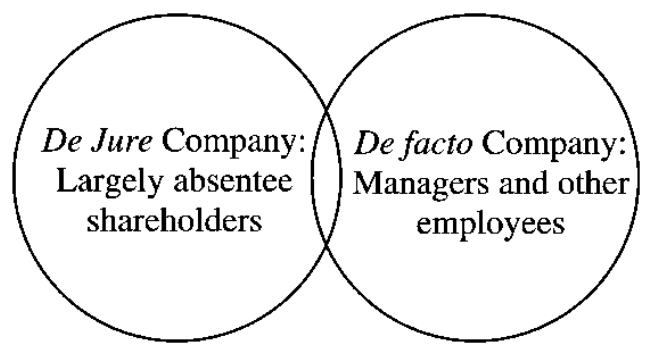

Figure 3. The two companies in a publicly traded American 'company'

company. The shareholders are seen as the insiders, principals, members, and owners of the (de jure) company. When things are not going well, the shareholders are legally empowered to change 'their company'. And since the people who actually work in the company, the de facto company, are seen legally as having only a market relationship to the company (the employment relation), their role is modelled on an exit-based logic.

In the Anglo-American economies, starting from closely-held firms (with little divergence between the de jure and de facto firms) the growth of the public market in equity shares has created these rather odd chimeras. And as the de jure firm ('ownership') has diverged more and more from the actual firm, the legal theory broke down. The transaction costs for dissatisfied far-flung shareholders to organize and actually change things were very high. And the returns from organizing enough shareholders would be shared by all shareholders, so there was also a strong collective action problem. Hence shareholders used the 'Wall Street Rule'; if you don't like the way things are going, exit by selling your shares.

Hence, the people legally empowered to implement a commitment-based strategy ('change things') use a de facto exit-based strategy (sell). And the managers and workers who are de facto in a position to implement a commitment-oriented strategy ('change things') are seen legally as being outsiders ('employees') on the other end of a market relationship with the company. They are not the principals or owners directly empowered by corporate law to change things - so in the eyes of the law, their only option is to quit ('exit') if they are dissatisfied (love it or leave it). Any attempt of workers to organize in unions to secure rights in the firm is seen as antithetical to the exit-based logic of competitive markets. The union is seen as the party on the other side of a contract with the company, not as a part of the internal governance structure of a company. Any attempt of the workers, the members of the de facto firm, to formalize powers to directly 'change things' is seen as infringing on the 'management rights' exercised by the supposed agents of the far-flung shareholders who are the legal members of the company.

Of course, this bizarre structure would not actually work. Some insiders gladly grabbed the levers of actual control dropped by the shareholders. Those insiders are the top managers, so we arrive at what Adolf Berle and 
Gardner Means called the 'separation of ownership and control' (Berle \& Means, 1932: 89) and at what is currently called the 'corporate governance problem.' The legal theory or 'model' is shareholder capitalism; the underlying actuality is managerial capitalism. ${ }^{15}$

And from the motivational viewpoint, the bizarre model structure would not work unless those who are legally outsiders on the other end of the employment contract - getting only the economic reward of salary or wage - were to a significant degree committed to and identified with the company. Although this is almost entirely ignored by conventional exitoriented economics, Economics Nobel-laureate Herbert Simon has emphasized the point.

Organizations would be far less effective systems than they actually are if such (economic) rewards were the only means, or even the principal means, of motivation available. In fact, observation of behavior in organizations reveals other powerful motivations that induce employees to accept organizational goals and authority as bases for their actions. ... [The] most important of these mechanisms [is]: organizational identification. (Simon, 1991: 34)

Hence, the members of the de facto company do in fact tend to identify with the company even though they are legally outside the company!

The large American firm is actually a rather odd and incoherent organization. Those who are legally inside the firm (shareholders) act as if they were outside, and those who are legally outside the firm (employees) act as if they were inside.

This mismatch between the model and reality leaves the analyst in a quandary. Should one analyse the rather mythical company model as it exists in the lawbooks and in the economics textbooks? That is the 'American model' broadcast to the world by ivory tower academics who might think that American companies actually work that way. But since actual organizations need a healthy dose of commitment-oriented behaviour to work well, the archetypal exit-oriented 'American model' is a textbook model only. The actual large widely-held American companies use a version of the logic of commitment. But the top managers who assume and exercise the legal rights of the insiders (owners) often try to treat all the other employees as outsiders on an exit-based model (e.g. in the labour relations system). Hence the actual large widely-held American firm ends up being something of a contested battleground between the two logics.

\footnotetext{
${ }^{15}$ Since there is no legal legitimation for the actual system, the public relations machinery in the companies, in the business press, and in academia broadcasts the goal of 'maximizing shareholder value' while the managers show their actual goals in their salaries, benefits, perquisites, (manipulated) stock options, and golden parachutes.
} 
In any case, for analytical purposes we will juxtapose two rather pure models, a firm organized on an exit-based model and a firm organized on a commitment-based model.

\section{The Modern Japanese Company}

In their introduction to a book of essays by Japanese authors about the Japanese-style firm, Ronald Dore and Hugh Whittaker echo Herbert Simon, at least about the Japanese case: 'Most of the authors would agree that if you want to understand what goes on in Japanese boardrooms, you can throw most of the writings that go under the rubric "agency theory" out of the window' (Dore \& Whittaker, 1994: 3).

In the post-war era, the large Japanese firms have perhaps gone the furthest to develop the organizational logic of commitment and to contrast it with the logic of exit. For instance, to one trained to think in terms of the logic of exit, any immobilities, rigidities, or barriers to exit would just seem inefficient and irrational. But Japanese economists have evoked the example of useful barriers to exit, as in the practice of a captain being expected to go down with his ship.

The way in which underpayment of wages in the early years of service and the acquisition of firm-specific skills create barriers to exit is obvious. These exit barriers perform several important functions for the firm as an organizational entity. The first is the incentive function whereby the interests of the firm and the interests of the individual are linked. Unable easily to exit, people can only protect their interests by working to ensure that the firm prospers.... The interlinking of interests means that when crisis looms, efforts are redoubled. The option of leaving the sinking ship is not freely available, either to the crew or the captain. (Kagono \& Kobayashi, 1994: 94)

Barriers to exit can enhance identification and thus X-efficiency. ${ }^{16}$ During the last quarter century, the township-village enterprises (TVEs) have been a driving part in the remarkable Chinese transition. But their success has been something of a mystery to the orthodox economic viewpoint - lack of conventional ownership and lack of labour market flexibility. The TVEs exemplified the logic of commitment. The management identified with the staff since they had to provide jobs and related services to the people of the township or village, and the workers identified with the firm since that was their one chance for a good job (the Chinese government tried to prevent free mobility).

\footnotetext{
${ }^{16} \mathrm{~A}$ perfect labour market is similar to perfect insurance in that it gives workers no incentive to put forth effort (i.e. improve their effort characteristics) since, if caught shirking, they can exit and costlessly find the equivalent job elsewhere. The efficiency wage hypothesis is that firms will introduce imperfections by paying more than the going wage for a standard type of work so that workers will have something to lose if found to be shirking. See Akerlof \& Yellen (1986).
} 
The loss in allocative efficiency due to factor immobility seems to have been more than counterbalanced by the increase in X-efficiency since the Chinese growth episode over the last quarter century is the largest in recorded history.

A simple cooperative action game (of the prisoner's dilemma variety) can be used to illustrate the difference between a company based on low trust with individual optimization and a company based on high trust, identification with the firm, and a cooperative corporate culture (see Leibenstein, 1984, for the best treatment of this approach to the Japanese firm). The players A and B could be thought of as managers and workers (or as any two groups in the firm) who need to cooperate together to increase the X-efficiency of the firm (see Table 1). If each player chooses the individualistic notcooperate action, then they receive the non-cooperative payoff of $\$ \mathrm{~A}$ and $\$ \mathrm{~B}$. If they cooperate, then the total results increases by (say) 2 which we assume is evenly split to arrive at the cooperative payoffs of $\$ \mathrm{~A}+1$ and $\$ \mathrm{~B}+1$. But if one party opportunistically chooses the individualistic non-cooperative option when the other party acts cooperatively, then the total result remains the same (no increase without cooperation of parties) and two units are shifted to the opportunistic party. The strategy pair (Not Cooperate, Not Cooperate) is the dominant equilibrium solution. No matter which strategy one player chooses, it will always pay the other player to take the noncooperative action. But that non-cooperative outcome $(\$ \mathrm{~A}, \$ \mathrm{~B})$ is dominated by the cooperative outcome $(\$ A+1, \$ B+1)$ which is better for both parties.

This prisoner's dilemma-type game is a generic representation of the countless cooperative action situations that occur continuously and at every level in the complex multi-person productive operation of a firm. In each given situation, effective monitoring and enforcement might be applied at a certain cost to change the payoffs and thus assure the cooperative outcome. But this 'external' neoclassical solution is hardly feasible over the countless cooperative action situations that occur in a complex team operation.

The question is not whether free riders exist - much less employees who exert something less than their maximum - but why there is anything besides free-riding. Why do many workers, perhaps most, exert more than minimally enforceable effort? Why do employees identify with organizational goals at all? (Simon, 1991: 34)

That question is left unanswered in the exit-based American-style model. The Japanese-style company uses the alternative 'internal' solution of developing

Table 1. Typical cooperative action game

\begin{tabular}{llll}
\hline & Payoff to Player A, B & $\begin{array}{c}\text { Payoff to } \\
\text { Cooperate }\end{array}$ & $\begin{array}{c}\text { Player B } \\
\text { Not Cooperate }\end{array}$ \\
\hline $\begin{array}{l}\text { Payoff to } \\
\text { Player A }\end{array}$ & Cooperate & $\$ \mathrm{~A}+1, \$ \mathrm{~B}+1$ & $\$ \mathrm{~A}-2, \$ \mathrm{~B}+2$ \\
\hline
\end{tabular}


a corporate culture of mutual commitment and cooperation that leads to a virtuous circle or high level self-reinforcing equilibrium. This cooperative culture is feasible because the managers and workers see themselves as the members of a commitment-based community and will reap the joint fruits of their cooperative efforts.

One logic or the other ramifies through all the aspects and structures of a firm. Sometimes a firm organized on the logic of exit is stereotyped as the 'American firm' and a firm organized on the logic of commitment is the 'Japanese firm' or 'J-firm.' (Aoki, 1988) But without promoting stereotypes, we can still summarize and compare in the following table some of the ways that the two logics affect firm structure. ${ }^{17}$

\section{Ownership for Liquidity or for Enterprise?}

Perhaps the last line of Table 2 requires some explanation. We can distil this wisdom from the academic scribblings of the defunct economist, John Maynard Keynes. Lord Keynes was much concerned with the adverse effects of the stock exchange on real investment and enterprise. Investment in productive enterprise is largely irrevocable, and the management of enterprise requires a long term commitment and the application of 'intelligence to defeat the forces of time and ignorance of the future...' (Keynes, 1936: 157). ${ }^{18}$ In short, it is based on the logic of loyalty and commitment. But when investment is securitized as a marketable asset on the stock exchange, then it 'is as though a farmer, having tapped his barometer after breakfast, could decide to remove his capital from the farming business between 10 and 11 in the morning and reconsider whether he should return to it later in the week' (Keynes, 1936: 151). The stock exchange panders to the 'fetish of liquidity' and thus continually undermines the bonds of long-term commitment that are so important to problem-solving and productive enterprise. Keynes, of course, wrote this long before today's problems with stock options and short-termism. Today's practice of the captain's exit facilitated by a golden parachute is the opposite of the practice of the captain going down with the ship (or falling on his sword).

In addition to this continual erosive effect, the stock exchange also absorbs otherwise productive capital in the function of speculation - which Keynes defined as 'the activity of forecasting the psychology of the market' (Keynes, 1936: 158). Keynes saw no problem when speculation was but a bubble on the stream of enterprise, but it was quite another matter 'when enterprise becomes a bubble on a whirlpool of speculation. When the capital development of a country becomes a by-product of the activities of

\footnotetext{
${ }^{17}$ See Clark (1979) or Dore (1987) for similar tables.

${ }^{18}$ In the same vein, Hirschman refers to 'that "long confrontation between man and a situation" (Camus) so fruitful for the achievement of genuine progress in problem-solving' (Hirschman, 1973: 240).
} 
Table 2. Two firms

\begin{tabular}{|c|c|c|}
\hline & $\begin{array}{c}\text { Firm based on Logic } \\
\text { of Exit }\end{array}$ & $\begin{array}{l}\text { Firm based on Logic } \\
\text { of Commitment }\end{array}$ \\
\hline Efficiency & $\begin{array}{l}\text { Allocative efficiency: moving } \\
\text { resources to the use with } \\
\text { the best return. (high } \\
\text { mobility). }\end{array}$ & $\begin{array}{l}\text { X-efficiency: getting the best } \\
\text { return from resources in the } \\
\text { given uses. (low mobility) }\end{array}$ \\
\hline Change Strategy & $\begin{array}{l}\text { Replace what you have with } \\
\text { something better. Problem } \\
\text { is to improve choice among } \\
\text { options with fixed } \\
\text { characteristics. }\end{array}$ & $\begin{array}{l}\text { Transform what you have into } \\
\text { something better. Problem is } \\
\text { the transformation of given } \\
\text { option to improve its } \\
\text { characteristics. }\end{array}$ \\
\hline $\begin{array}{l}\text { Source of flexibility } \\
\text { and change }\end{array}$ & $\begin{array}{l}\text { Exit (change takes place } \\
\text { through entry and exit } \\
\text { from the organization). } \\
\text { Rather flight than fight. } \\
\text { Error leads to replacement. }\end{array}$ & $\begin{array}{l}\text { Voice (change takes place by } \\
\text { transformation within } \\
\text { organization). Rather fight } \\
\text { than flight. Error leads to } \\
\text { learning. }\end{array}$ \\
\hline Labour mobility & $\begin{array}{l}\text { High mobility so changes } \\
\text { take place primarily by } \\
\text { hiring workers embodying } \\
\text { new knowledge. }\end{array}$ & $\begin{array}{l}\text { Low mobility so changes take } \\
\text { place primarily by workers } \\
\text { learning new knowledge and } \\
\text { skills. }\end{array}$ \\
\hline Contractual relationships & Arms-length. & Relational. \\
\hline Role of management & Agents of shareholders. & Senior leaders of community. \\
\hline Role of company board & $\begin{array}{l}\text { Representatives of } \\
\text { shareholders. }\end{array}$ & $\begin{array}{l}\text { Council of community elders } \\
\text { with representatives of } \\
\text { major related organizations } \\
\text { (e.g., main bank). }\end{array}$ \\
\hline Role of shareholders & Absentee investors. & $\begin{array}{l}\text { One of stakeholder groups } \\
\text { along with suppliers and } \\
\text { customers. }\end{array}$ \\
\hline Shareholder interest & $\begin{array}{l}\text { Maximization of company } \\
\text { profit (assumption that } \\
\text { shareholders are normally } \\
\text { unrelated to company). }\end{array}$ & $\begin{array}{l}\text { Shareholding often } \\
\text { representative of business } \\
\text { relationships, the latter being } \\
\text { the primary economic } \\
\text { interest. Little attention to } \\
\text { unrelated floating } \\
\text { shareholders. }\end{array}$ \\
\hline $\begin{array}{l}\text { Transactions with related } \\
\text { shareholders }\end{array}$ & $\begin{array}{l}\text { To be controlled by } \\
\text { independent directors or } \\
\text { forbidden by 'firewall' } \\
\text { regulations. }\end{array}$ & $\begin{array}{l}\text { Normal part of relational } \\
\text { contracting where } \\
\text { shareholding is symbolic of } \\
\text { business relationship (called } \\
\text { 'cronyism' by critics). }\end{array}$ \\
\hline $\begin{array}{l}\text { Model of supplier } \\
\text { relationships }\end{array}$ & $\begin{array}{l}\text { Competition between } \\
\text { standardized producers } \\
\text { with feedback through the } \\
\text { market. }\end{array}$ & $\begin{array}{l}\text { Cooperation with a small } \\
\text { number of suppliers to } \\
\text { continuously improve } \\
\text { product through non-market } \\
\text { feedback. }\end{array}$ \\
\hline
\end{tabular}


Table 2. Continued

\begin{tabular}{|c|c|c|}
\hline & $\begin{array}{c}\text { Firm based on Logic } \\
\text { of Exit }\end{array}$ & $\begin{array}{l}\text { Firm based on Logic } \\
\text { of Commitment }\end{array}$ \\
\hline $\begin{array}{l}\text { Relations to suppliers } \\
\text { and customers }\end{array}$ & $\begin{array}{l}\text { Auction market contracting } \\
\text { based on assumption of } \\
\text { mobility and exit leading to } \\
\text { greater allocative efficiency }\end{array}$ & $\begin{array}{l}\text { Relational contracting based } \\
\text { on assumption of immobility } \\
\text { and voice leading to greater } \\
\text { X-efficiency }\end{array}$ \\
\hline Stability in relationships. & $\begin{array}{l}\text { Low trust relationships } \Rightarrow \\
\text { highly explicit contracts } \\
\text { with competitive arms- } \\
\text { length exit-oriented } \\
\text { relationships so no need to } \\
\text { invest in building trust } \Rightarrow \\
\text { low trust relationships. }\end{array}$ & $\begin{array}{l}\text { High trust relationships } \Rightarrow \\
\text { incomplete relational } \\
\text { contracts with voice- } \\
\text { oriented relationships } \\
\text { requiring investment in } \\
\text { building trust } \Rightarrow \text { high trust } \\
\text { relationships. }\end{array}$ \\
\hline $\begin{array}{l}\text { Style of interpersonal } \\
\text { relationships. }\end{array}$ & $\begin{array}{l}\text { Standardized, } \\
\text { professionalized behaviour } \\
\text { as a means of coordinating } \\
\text { people. Low interpersonal } \\
\text { knowledge associated with } \\
\text { high turnover. }\end{array}$ & $\begin{array}{l}\text { Familiarity, intimacy in long- } \\
\text { term relationships as means } \\
\text { of coordinating people. High } \\
\text { interpersonal knowledge } \\
\text { associated with low } \\
\text { turnover. }\end{array}$ \\
\hline Labour training & $\begin{array}{l}\text { Responsibility of worker as it } \\
\text { increases value on labor } \\
\text { market. }\end{array}$ & $\begin{array}{l}\text { Responsibility of company } \\
\text { since immobility allows } \\
\text { company to benefit. }\end{array}$ \\
\hline Job definition & $\begin{array}{l}\text { Extensively specified job } \\
\text { definition to limit } \\
\text { opportunism since there is } \\
\text { little commitment. }\end{array}$ & $\begin{array}{l}\text { Job flexibility and low } \\
\text { monitoring based on worker } \\
\text { commitment to company. }\end{array}$ \\
\hline ermination & $\begin{array}{l}\text { Rate for job determined by } \\
\text { market. Payment attached } \\
\text { to job. Equal pay for equal } \\
\text { work. }\end{array}$ & $\begin{array}{l}\text { Rate determined by seniority } \\
\text { and assessed merit. Payment } \\
\text { attached to person. Under } \\
\text { going-rate at beginning and } \\
\text { over it at end as an incentive } \\
\text { to stay. }\end{array}$ \\
\hline Worker motivation & $\begin{array}{l}\text { Individual pecuniary self- } \\
\text { interest (non-cooperative } \\
\text { strategy). }\end{array}$ & $\begin{array}{l}\text { Members expected to identify } \\
\text { with firm and shared interest } \\
\text { (cooperative strategy). }\end{array}$ \\
\hline $\begin{array}{l}\text { Organized worker } \\
\text { representation }\end{array}$ & $\begin{array}{l}\text { Trade union (adversary } \\
\text { relation based on workers } \\
\text { versus company) - my jam } \\
\text { or your jam. }\end{array}$ & $\begin{array}{l}\text { Enterprise union (oppositional } \\
\text { relation loyal to company) - } \\
\text { our jam today or our jam } \\
\text { tomorrow. }\end{array}$ \\
\hline Response to decline & $\begin{array}{l}\text { Reduce employment and } \\
\text { other direct costs to } \\
\text { maintain profits. }\end{array}$ & $\begin{array}{l}\text { Maintain employment, reduce } \\
\text { hours, and retrain workers } \\
\text { for new product lines. }\end{array}$ \\
\hline Business ownership & $\begin{array}{l}\text { Stock market liquidity. Firm } \\
\text { as 'investment.' }\end{array}$ & $\begin{array}{l}\text { Illiquidity of closely-held } \\
\text { business. Firm as enterprise. }\end{array}$ \\
\hline
\end{tabular}




\section{4}

a casino, the job is likely to be ill-done' (Keynes, 1936: 159). This is even more true when the casino is global rather than national.

Today, Keynes' 'stock exchange' must be updated to the global market for bonds, stocks, and currencies. The dangers to investment in enterprise that Keynes highlighted during his day are even greater in our own. Yet Keynes recognized that there is no simple answer in making investment illiquid as 'this might seriously impede new investment...' Few will enter if the door locks behind them. 'This is the dilemma' (Keynes, 1936: 160). But since investors on today's public capital markets are not enterprisers, the solution lies in the direction of converting equity shares into variable income debt-like instruments that are still liquid.

\section{Another Look at the Choices}

Since the American 'model' is essentially only a textbook and lawbook model, to what extent is it really a possible option? In the American model, the employees have the legal role as the outside suppliers of an input - but in fact they are the firm as an organization of people. This leads to a remarkable schizophrenia of the 'two companies'. There is the firm in the eyes of the law whose members are the shareholders scattered far and wide, and who typically trade into the stock simply as an investment without any intent or capacity to play a human role in the firm. This is the firm that has a 'meeting' once a year. In contrast to this de jure firm, there is the de facto firm consisting of the people who work in the firm - who have a meeting every working day to actually produce the product and conduct the business of the firm.

The large widely-held American company actually works because most of those who are legally inside realize that they are really outside and act like it (absentee shareholders using logic of exit), and most of those who are legally outside the company act like they are inside it (employees identifying with the company). Thus the actual American-style company is torn between the two logics, and tends to work well only when it ignores the exit-oriented design logic and uses the logic of commitment. While this type of company is extremely beneficial to the class of top managers, it is not clear how such an incoherent structure torn between the two logics could be recommended more broadly in Korea or elsewhere.

In Figure 3, the two companies were presented as a Venn diagram of two overlapping circles. There are four areas, the two parts in one circle but not the other, the overlap, and the area outside both circles. These four areas can also be represented in the $2 \times 2$ format of Table 3 with the parties in or out of the legal (de jure) firm and in or out of the de facto firm. Ordinary consciousness often reflects the de facto company. The employees are often thought of as the members of the organization. Consider the following from a perfectly standard managerial accounting textbook.

An organization can be defined as a group of people united together for some common purpose. A bank providing financial services is an 
Table 3. Who's in and who's out of the two companies

\begin{tabular}{|c|c|c|}
\hline & Inside de facto company & Outside de facto company \\
\hline Inside legal company & $\begin{array}{l}\text { Shareholder-members } \\
\text { working in company }\end{array}$ & $\begin{array}{l}\text { Absentee 'members' } \\
\text { (shareholders) of company }\end{array}$ \\
\hline Outside legal company & Employees of company & $\begin{array}{l}\text { Suppliers of things } \\
\text { to company }\end{array}$ \\
\hline
\end{tabular}

organization, as is a university providing educational services, and the General Electric Company producing appliances and other products. An organization consists of people, not physical assets. Thus, a bank building is not an organization; rather, the organization consists of the people who work in the bank and who are bound together for the common purpose of providing financial services to a community. (Garrison, 1979: 2)

Garrison is talking entirely about the de facto company, not the company as it exists in law. Look at the books on the business shelves in your local bookstore. Find a book that uses some expression like 'members' of the company. Chances are that the author, like Garrison above, is referring to the employees (including managers) of the firm, not the far-flung shareholders (who are the legal 'members').

As Anglo-American stock markets have spread shares far and wide, the idea that the stockholders are in any real sense the 'owners' or 'members' of a publicly traded company has become a sheer fantasy. And there are several groups invested in keeping the fantasy alive. Many economists and lawyers have acquired their professional competence in mastering the legal model and the economic logic of exit behind it. Anything else falls short of the One Best Model. In addition, there are the top managers who have mightily profited from the eclipse of the shareholders. They have every interest in keeping the fantasy of 'shareholder capitalism' alive as the cover-story for the reality of managerial capitalism - much as the nomenklatura of the Communist Party had every interest in keeping the fantasy of 'People's Democracy' alive.

What Berle and Means described as the 'separation of ownership and control', John Maynard Keynes described as the 'euthanasia of the rentier, of the functionless investor' (Keynes, 1936: 376) caused by the public equity markets. This separation of ownership and control along with the unaccountability of managers and the resulting abuses has created the 'corporate governance problem.' Who are to be the new legitimate members of the company? While a few wistfully hope for the resurrection of 'responsible private owners' in the form of massive institutional investors run by portfolio-managing bureaucrats, others search the horizon for various 'stakeholders' who together with the regulatory agencies and law courts might create a 'new accountability.' But they are searching for legitimacy in all the wrong places. 
There already is a class of members who make up the firm, the de facto firm consisting of the people who work in it. In a company designed on the basis of the logic of commitment, they would be the legal members of the company (which would remove the off-diagonal elements in the Table 3). Many parties have their interests affected by a company, and better judicial and regulatory oversight is needed to protect those legitimate outside interests. But since the staff of a company are the de facto firm, they are the ones who could actually monitor the management of their company to address the corporate governance problem directly.

The only cohesive, workable, and effective constituency within view is the corporation's work force. (Flynn, 1973: 106)

\section{Concluding Remarks}

Economics is by far the most prestigious and dominant of the social sciences. The initial successes of economics have been in modelling market behaviour, which is based on the logic of exit. Hence, 'exit' has become 'the' mechanism of economics. The exit-oriented logic is the answer to all questions of institutional design; it is the One Best Way. For instance, under the exit-oriented logic, all labour questions are 'labour market' questions while under the alternative commitment-oriented logic (e.g. in a Japanese-style firm), a labour question is a 'human relations' or 'human resources' question. ${ }^{19}$

My purpose has been to complicate that discourse - to show that there is a dual logic of series- or commitment-oriented institutional design. If an option with its current characteristics is unsatisfactory, then the alternative to exiting the option is - on the basis of loyalty and commitment to the option - to use voice to change the characteristics.

Economics is clear on how competition can lead failing firms to exit the market through bankruptcy.

But, as far as I have been able to ascertain, no study, systematic or casual, theoretical or empirical, has been made of the related topic of competition's ability to lead firms back to 'normal' efficiency, performance, and growth standards after they have lapsed from them. (Hirschman, 1970: 22)

Such a messy topic might be considered in the more practical literature on management.

\footnotetext{
${ }^{19}$ For instance, the advice of the World Bank to developing countries about labour is in the 'labor markets' topic area (see http://www1.worldbank.org/sp/); there is no 'human resources' topic area. But for its own staff within the World Bank, there is a Human Resources Vice President but no 'Labor Market Vice President.' Thus the Bank looks outward through an exitoriented lens and inward through a commitment-oriented lens.
} 
My task has been to try to counter the one-sidedness of the economics literature by emphasizing the alternative logic of commitment-oriented institutional design. The exit-based American model as it exists in the textbooks and lawbooks is actually rather unworkable. There has been the constant attempt to implement the pure exit-oriented model (at least for non-managerial employees) throughout the twentieth century. However, actual American companies use more of a logic of commitment, but because the design conflicts with the actuality, it is constantly being contested. The Japanese-style firm is a major example of an organizational design and an actuality that coheres with the design - both based on the organizational logic of commitment. In order better to understand commitment-based design, our task has been to elucidate and contrast the two logics of institutional design.

\section{References}

Akerlof, George \& Yellen, Janet (Eds) (1986) Efficiency Wage Models of the Labor Market (Cambridge: Cambridge University Press).

Aoki, Masahiko (1988) Information, Incentives, and Bargaining in the Japanese Economy (New York: Cambridge University Press).

Axelrod, Robert \& Cohen, Michael (1999) Harnessing Complexity: Organizational Implications of a Scientific Frontier (New York: Free Press).

Berle, Adolf \& Means, Gardiner (1932) The Modern Corporation and Private Property (New York: Macmillan).

Blair, Margaret M. (1995) Ownership and Control: Rethinking Corporate Governance for the TwentyFirst Century (Washington, DC: The Brookings Institution).

Clark, Rodney (1979) The Japanese Company (New Haven, CT: Yale University Press).

Dore, Ronald (1987) Taking Japan Seriously (Stanford, CA: Stanford University Press).

Dore, Ronald \& Whittaker, Hugh (1994) Introduction, in: K. Imai \& R. Komiya (Eds) Business Enterprise in Japan: Views of Leading Japanese Economists, pp. 1-15 (Cambridge: MIT Press).

Ellerman, David (1995) Intellectual Trespassing as a Way of Life: Essays in Philosophy, Economics, and Mathematics (Lanham, MD: Rowman \& Littlefield).

Ellerman, David (2003) Policy Research on Migration and Development. World Bank Policy Research Working Papers (No. 3117), pp. 1-64 (Washington DC: World Bank).

Flynn, John J. (1973) Corporate democracy: nice work if you can get it, in: R. Nader \& M. J. Green (Eds) Corporate Power in America, pp. 94-110 (New York: Grossman Publishers).

Freeman, Richard \& Medoff, James (1984) What Do Unions Do? (New York: Basic Books).

Garrison, Ray (1979) Managerial Accounting (Dallas, TX: Business Publications Inc.).

Goldberg, Victor (1980) Relational exchange: economics and complex contracts, American Behavioral Scientist, 23(3), January/February, pp. 337-352.

Hirschman, Albert O. (1958) The Strategy of Economic Development (New Haven, CT: Yale University Press).

Hirschman, Albert O. (1970) Exit, Voice, and Loyalty: Responses to Decline in Firms, Organizations, and States (Cambridge, MA: Harvard University Press).

Hirschman, Albert O. (1973) Journeys Toward Progress (New York: Norton).

Jacobs, Jane (1984) Cities and the Wealth of Nations: Principles of Economic Life (New York: Random House).

Jacobs, Jane (1992) Systems of Survival: A Dialogue on the Moral Foundations of Commerce and Politics (New York: Vintage Books). 


\section{David Ellerman}

Kagono, Tadao \& Kobayashi, Takao (1994) The provision of resources and barriers to exit, in: K. Imai \& R. Komiya (Eds) Business Enterprise in Japan, pp. 89-102 (Cambridge, MA: MIT Press).

Keynes, John Maynard (1936) The General Theory of Employment, Interest, and Money (New York: Harcourt, Brace \& World).

Leibenstein, Harvey (1966) Allocative efficiency versus X-efficiency, American Economic Review, 56(3), June, pp. 392-415.

Leibenstein, Harvey (1984) The Japanese management system: an X-efficiency game theory analysis, in: M. Aoki (Ed.) The Economic Analysis of the Japanese Firm, pp. 331-357 (Amsterdam: Elsevier).

McGregor, Douglas (1960) The Human Side of Enterprise (New York: McGraw-Hill).

Pagels, Heinz (1988) The Dreams of Reason: The Computer and the Rise of the Sciences of Complexity (New York: Bantam).

Rockafellar, R. Tyrrell (1970) Convex Analysis (Princeton, NJ: Princeton University Press).

Scott, W. Richard (1998) Organizations: Rational, Natural, and Open Systems, 4th edn (Upper Saddle River, NJ: Prentice Hall).

Simon, Herbert (1991) Organizations and markets, Journal of Economic Perspectives, 5(2), Spring, pp. 25-44.

Strang, Gilbert (1986) Introduction to Applied Mathematics (Wellesley, MA: Wellesley-Cambridge Press).

Von Alven, William (Ed.) (1964) Reliability Engineering (Englewood Cliffs, NJ: Prentice-Hall). 